\title{
Influence of Antioxidant Administration during Periparturient Period on Total Antioxidant Status in Surti Buffaloes
}

\author{
L.C. Modi ${ }^{1 *}$, C.T. Khasatiya ${ }^{1}$, Sandhya Chaudhary ${ }^{2}$, N.F. Chaudhari ${ }^{1}$, \\ C.F. Chaudhari ${ }^{1}$ and Falguni Modi ${ }^{3}$
}

${ }^{1}$ Department of Veterinary Gynaecology and Obstetrics, ${ }^{2}$ Department of Veterinary Physiology \& Biochemistry, ${ }^{3}$ Department of Veterinary Pharmacology \& Toxicology, College of Veterinary Science and Animal Husbandry, Navsari Agricultural University, Navsari, Gujarat-396 450, India

*Corresponding author

\section{A B S T R A C T}

Keywords

Antioxidant,

Transient period,

Total antioxidant

status, Buffaloes

\section{Article Info}

Accepted:

15 September 2018

Available Online:

10 October 2018
The animals were divided into two groups comprising of ten animals in each group as: Group-I: Treatment group of Surti buffaloes treated with Inj. Vitamin E and Selenium (ECARE Se) on $60^{\text {th }}, 45^{\text {th }}, 30^{\text {th }}$ and $15^{\text {th }}$ day before expected date of parturition and after parturition on $15^{\text {th }}, 30^{\text {th }}$ day and Group-II: Control group given Inj. Normal Saline (IM) as placebo treatment. The mean plasma Total Antioxidant Status (TAS) concentration did not differ significantly $(\mathrm{p}>0.05)$ at different days interval in between treatment and control groups. The pooled mean plasma TAS level was found significantly $(p<0.05)$ decreased in trend from $60^{\text {th }}$ day to $45^{\text {th }}$ day, $30^{\text {th }}$ day and $15^{\text {th }}$ day pre partum and on the day of calving and there after significantly $(\mathrm{p}<0.05)$ increased in trend at $15^{\text {th }}$ day, $30^{\text {th }}$ day and nonsignificantly $(\mathrm{p}>0.05)$ increased at $45^{\text {th }}$ day and thereafter significantly $(\mathrm{p}<0.05)$ increased at $60^{\text {th }}$ day post partum in Surti buffaloes. The mean plasma TAS concentration did not differ significantly $(p>0.05)$ in between pregnant and non-pregnant groups at different days interval except at $60^{\text {th }}$ days prepartum it was significantly $(\mathrm{p}<0.05)$ higher in pregnant group as compared to non-pregnant group.

\section{Introduction}

The transition or periparturient period, from 3 weeks before to 3 weeks after parturition, is a stressful time for dairy cows (Drackley, 1999). An imbalance between increased production of ROS and reduced availability of antioxidant defenses near the time of parturition increases oxidative stress and may contribute to periparturient disorders in dairy cows (Gitto $e t$ al., 2002). During gestation oxidative stress plays a role in the initiation of pre-term labor (Pressman et al., 2003) and during normal parturition (Fainaru et al., 2002) assuring ovulation, ovarian steroidogenesis, oocyte maturation, blastocyst formation, luteolysis and luteal maintenance in pregnancy (Sugino et al., 2000). Total Antioxidative Capacity 
(TAC) is defined as a measure of overall freeradical scavenging potential (Paszkowski and Clarke, 1996). Quantification of a single antioxidant often tells little about whole body defense, making it necessary to evaluate multiple indicators of redox status. Although, measuring multiple antioxidants or biomarkers of stress is helpful, measuring a myriad of variables also tends to be impractical. Consequently, total antioxidant capacity assays are being employed on a routine basis. Vitamin $\mathrm{E}$ is an important antioxidant that has been shown to play an important role in immuno responsiveness and health in dairy cows (Weiss and Spears, 2006). Morover, vitamin $\mathrm{E}$ is involved in the formation of leukotrins, prostaglandin and postacyclin and has got a role in the duration of postpartum interval. In Vitamin $\mathrm{E}$ and Selenium deficiency condition, free radicals accumulate and not only damage cell membranes, but also disrupt several processes linked to the synthesis of steroids (Seagerson and Libby, 1982) and prostaglandins (Harrison and Conrad, 1984).

\section{Materials and Methods}

The present research work was undertaken on twenty (20) Surti buffaloes during their transient period i.e. two month before their expected date of parturition to two month after parturition, dividing into treatment $(n=10) \&$ control $(n=10))$ groups, at Livestock Research Station, Navsari Agricultural University, Navsari, Gujarat, over a period from May, 2014 to April, 2015. The animals were fed green fodder, hay and compounded concentrate, as per the standard feeding schedule followed on the farm. The animals had free access to drinking water. The animals were also washed and sprinkled with water twice daily or were allowed to wallow in the pond during hot noon hours of summer season to reduce heat stress and to improve oestrus expression in them. In control group of 10 animals to which $10 \mathrm{ml}$ normal saline injected IM on $60^{\text {th }}, 45^{\text {th }}, 30^{\text {th }}$ and $15^{\text {th }}$ day before expected date of parturition and after parturition on $15^{\text {th }}, 30^{\text {th }}$ day. Treatment Group of 10 animals to which the injectable product E-CARE Se (DL- $\alpha$ Tocopheryl Acetate I.P. equivalent to Tocopherol (Vitamin E) Base $50 \mathrm{mg}$, Sodium Selenite U.S.P. equivalent to Selenium Base $-1.5 \mathrm{mg}$ in each $\mathrm{ml}$ ) was administered IM on $60^{\text {th }}, 45^{\text {th }}, 30^{\text {th }}$ and $15^{\text {th }}$ day before expected date of parturition and after parturition on $15^{\text {th }}, 30^{\text {th }}$ day at the dose rate of $10 \mathrm{ml}$ (500 mg vit. E and $15 \mathrm{mg} \mathrm{Se}$.). Pregnancy diagnosis was carried out per rectally at 90 days post breeding. Again the group was made from all 20 animals irrespective of treatment and control group on the base of its conception in pregnant $(n=13)$ and non-pregnant $(n=7)$ groups.

\section{Blood collection and laboratory examination}

Blood samples were collected from all those selected animals on approximate day 60, 45, 30,15 before the expected date of parturition, on the day of parturition and 15, 30, 45 and 60 day after parturition in EDTA vaccutainer for plasma. The plasma was separated from vaccutainers containing $5 \mathrm{ml}$ blood samples immediately after its collection and stored at $20^{\circ} \mathrm{C}$ in deep freezer until analysis. Plasma total antioxidant activity was measured by ferric reducing antioxidant power (FRAP) assay (Benzie and Strain, 1999).

\section{Statistical analysis}

The tests of significance for pregnant vs. nonpregnant and treatment vs. control groups were made by Standard Student's paired ' $t$ ' test. The fortnight-wise variation within the group was tested for each trait by using completely randomized design as well as the mean differences between and within the groups were tested using Duncan's New 
Multiple Range Test (DNMRT) at 1 per cent and 5 per cent level of significance.

\section{Results and Discussion}

The mean plasma TAS concentrations varied non-significantly $(\mathrm{p}>0.05)$ between treatment and control groups at different peripartum intervals. The overall mean plasma TAS levels in treatment and control groups were nonsignificantly $\quad(p>0.05)$ higher before parturition as compared to after parturition, and thereby the overall prepartum pooled mean plasma was also non-significantly ( $p>0.05$ ) higher as compared to overall postpartum pooled mean $(1945.833 \pm 28.787$ vs. $1911.979 \pm 25.741 \mu \mathrm{m} / \mathrm{L})$. Similarly the overall mean plasma TAS value was nonsignificantly $(\mathrm{p}>0.05)$ higher in the treatment group as compared to control group at prepartum phase $(1969.792 \pm 41.773$ vs. $1921.875 \pm 39.786 \mu \mathrm{m} / \mathrm{L})$ and lower at postpartum phase $(1905.208 \pm 40.639$ vs. $1918.750 \pm 32.100 \mu \mathrm{m} / \mathrm{L})$, and thereby the overall pooled mean concentration was also non-significantly $(\mathrm{p}>0.05)$ higher in treatment group as compared to control group (1883.333 \pm 31.973 vs. $1863.426 \pm 29.422 \mu \mathrm{m} / \mathrm{L}$ ) (Table $1)$.

The prepartum TAS level was nonsignificantly $(p>0.05)$ higher when compared between prepartum and postpartum at various intervals, viz., at $60^{\text {th }}$ day prepartum than that of $60^{\text {th }}$ day postpartum; $45^{\text {th }}$ day prepartum than that of $45^{\text {th }}$ day postpartum; $30^{\text {th }}$ day prepartum than that of $30^{\text {th }}$ day postpartum and $15^{\text {th }}$ day prepartum than that of $15^{\text {th }}$ day postpartum in treatment group, whereas in control group it was found non-significantly $(p>0.05)$ lower at $60^{\text {th }}$ day prepartum than that of $60^{\text {th }}$ day postpartum; non-significantly ( $>0.05$ ) higher at $45^{\text {th }}$ day prepartum than that of $45^{\text {th }}$ day postpartum; $30^{\text {th }}$ day prepartum than that of $30^{\text {th }}$ day postpartum and nonsignificantly $(\mathrm{p}>0.05)$ lower at $15^{\text {th }}$ day prepartum than that of $15^{\text {th }}$ day postpartum (Table 1). The pooled mean plasma TAS level was found to be significantly $(p<0.05)$ decreased from $60^{\text {th }}$ day to $45^{\text {th }}$ day, $30^{\text {th }}$ day and $15^{\text {th }}$ day prepartum and on the day of calving and thereafter significantly $(p<0.05)$ increased at $15^{\text {th }}$ day, $30^{\text {th }}$ day and at $60^{\text {th }}$ day postpartum in Surti buffaloes. Almost same trend was found for treatment and control groups over peripartum intervals (Table 1).

The mean plasma TAS level was found nonsignificantly $(\mathrm{p}>0.05)$ higher on the day of calving $(1480.769 \pm 76.309$ vs. $1333.333 \pm$ $72.739 \mu \mathrm{m} / \mathrm{L}$ ) in pregnant group as compared to non-pregnant group (Table 1).

The mean plasma TAS level decreased significantly $(\mathrm{p}<0.05)$ from $60^{\text {th }}$ day prepartum $(2256.410 \pm 60.573 \mu \mathrm{m} / \mathrm{L} ; 2005.952 \pm$ $101.015 \mu \mathrm{m} / \mathrm{L})$ to the day of calving $(1480.769 \pm 76.309 \mu \mathrm{m} / \mathrm{L} ; 1333.333 \pm 72.739$ $\mu \mathrm{m} / \mathrm{L})$ and increased significantly $(\mathrm{p}<0.05)$ up to $30^{\text {th }}$ day postpartum $(1871.795 \pm 49.360$ $\mu \mathrm{m} / \mathrm{L}$ ) from day of parturition in the pregnant group and up to $15^{\text {th }}$ day postpartum $(1702.381 \pm 71.263 \mu \mathrm{m} / \mathrm{L})$ in the non-pregnant group, and thereafter non-significantly $(\mathrm{p}>0.05)$ increased at $60^{\text {th }}$ day postpartum $(2125.000 \pm 36.847 \mu \mathrm{m} / \mathrm{L} ; 2136.905 \pm 21.735$ $\mu \mathrm{m} / \mathrm{L}$ ) in both pregnant and non-pregnant groups of buffaloes (Table 1).

In the present study plasma total antioxidant activity (FRAP Values) declined from $60^{\text {th }}$ day prepartum till calving in both the groups, TAS was lowest on the day of calving in both the groups, whereas it was non-significantly ( $>0.05)$ higher in treatment group as compared to control group of Surti buffaloes and increased significantly $(\mathrm{p}<0.05)$ to reach the highest values at $60^{\text {th }}$ day postpartum. Higher total antioxidant status found in the treatment group as compared to control group in the present study might be ascribed to vitamin $\mathrm{E}$ and Se treatment in that group. 
Table.1 Mean plasma Total Antioxidant Status (TAS) levels $(\mu \mathrm{m} / \mathrm{L})$ at different fortnightly intervals peripartum in antioxidant treated and control groups as well as pregnant and non-pregnant groups of Surti buffaloes (Mean $\pm \mathrm{SE}$ )

\begin{tabular}{|c|c|c|c|c|c|c|c|c|}
\hline \multirow{2}{*}{$\begin{array}{c}\text { Peripartum } \\
\text { Phases }\end{array}$} & \multirow[t]{2}{*}{ Days } & \multicolumn{7}{|c|}{ Total Antioxidant Status (TAS) $\mu \mathrm{m} / \mathrm{L}$} \\
\hline & & $\begin{array}{c}\text { Treatment } \\
(n=10)\end{array}$ & $\begin{array}{l}\text { Control } \\
(n=10)\end{array}$ & $\begin{array}{c}\text { 't' - } \\
\text { Value }\end{array}$ & $\begin{array}{l}\text { Pooled } \\
(n=20)\end{array}$ & $\begin{array}{c}\text { Pregnant } \\
(n=13)\end{array}$ & $\begin{array}{c}\text { Non- pregnant } \\
(\mathbf{n}=7)\end{array}$ & $\begin{array}{c}\text { 't'- } \\
\text { value }\end{array}$ \\
\hline \multirow[t]{5}{*}{ Prepartum } & 60 & $2254.167 \pm 50.633^{\mathrm{e}}$ & $2083.333 \pm 100.539^{d}$ & 1.518 & $2168.750 \pm 58.182^{\mathrm{f}}$ & $\begin{array}{l}2256.410 \pm \\
60.573_{\mathrm{y}}^{\mathrm{e}}\end{array}$ & $2005.952 \pm 101.015_{x}{ }^{c d}$ & $2.266^{*}$ \\
\hline & 45 & $2037.500 \pm 38.011^{\mathrm{cd}}$ & $2008.333 \pm 39.675^{\mathrm{cd}}$ & 0.531 & $2022.917 \pm 26.948^{\text {de }}$ & $\begin{array}{l}2032.051 \pm \\
36.519^{\text {cd }}\end{array}$ & $2005.952 \pm 39.032^{\mathrm{cd}}$ & 0.452 \\
\hline & 30 & $1887.500 \pm 50.861^{\mathrm{c}}$ & $1879.167 \pm 49.865^{\text {bc }}$ & 0.117 & $1883.333 \pm 34.677^{\mathrm{c}}$ & $1887.821 \pm 48.432^{\mathrm{c}}$ & $1875.000 \pm 46.362^{\mathrm{bc}}$ & 0.172 \\
\hline & 15 & $1700.000 \pm 72.913^{b}$ & $1716.667 \pm 68.268^{b}$ & 0.167 & $1708.333 \pm 48.648^{b}$ & $1717.949 \pm 63.323^{b}$ & $1690.476 \pm 80.228^{b}$ & 0.263 \\
\hline & Overall & $1969.792 \pm 41.773$ & $1921.875 \pm 39.786$ & 0.831 & $1945.833 \pm 28.787$ & $1973.558 \pm 37.864$ & $1894.345 \pm 41.803$ & 1.319 \\
\hline $\begin{array}{c}\text { Day of } \\
\text { Parturition }\end{array}$ & 0 & $1450.000 \pm 87.797^{\mathrm{a}}$ & $1408.333 \pm 76.528^{\mathrm{a}}$ & 0.358 & $1429.167 \pm 56.882^{a}$ & $1480.769 \pm 76.309^{\mathrm{a}}$ & $1333.333 \pm 72.739^{\mathrm{a}}$ & 1.255 \\
\hline \multirow[t]{5}{*}{ Postpartum } & 15 & $1620.833 \pm 65.278^{b}$ & $1741.667 \pm 50.766^{\mathrm{b}}$ & 1.461 & $1681.250 \pm 42.564^{b}$ & $1669.872 \pm 54.910^{\mathrm{b}}$ & $1702.381 \pm 71.263^{b}$ & 0.356 \\
\hline & 30 & $1875.000 \pm 58.267^{\mathrm{c}}$ & $1850.000 \pm 51.670^{\mathrm{bc}}$ & 0.321 & $1862.500 \pm 38.008^{c}$ & $1871.795 \pm 49.360^{\mathrm{c}}$ & $1845.238 \pm 62.806^{b c}$ & 0.325 \\
\hline & 45 & $1975.000 \pm 56.656^{\mathrm{cd}}$ & $1975.000 \pm 56.995^{\mathrm{cd}}$ & 0.000 & $1975.000 \pm 39.110^{\mathrm{cd}}$ & $\begin{array}{l}1977.564 \pm \\
49.394^{\text {cd }}\end{array}$ & $1970.238 \pm 69.075^{\mathrm{cd}}$ & 0.087 \\
\hline & 60 & $2150.000 \pm 38.390^{\mathrm{de}}$ & $2108.333 \pm 31.793^{d}$ & 0.836 & $2129.167 \pm 24.724^{\mathrm{ef}}$ & $\begin{array}{l}2125.000 \pm \\
36.847^{\mathrm{de}}\end{array}$ & $2136.905 \pm 21.735^{\mathrm{d}}$ & 0.224 \\
\hline & Overall & $1905.208 \pm 40.639$ & $1918.750 \pm 32.100$ & 0.261 & $1911.979 \pm 25.741$ & $1911.058 \pm 32.906$ & $1913.691 \pm 41.718$ & 0.048 \\
\hline \multirow[t]{3}{*}{ Overall } & 't' - Value & 1.108 & 0.061 & -- & 0.877 & 1.246 & -0.328 & -- \\
\hline & P-Value & 0.271 & 0.951 & -- & 0.382 & 0.216 & 0.745 & -- \\
\hline & Pooled & $1883.333 \pm 31.973$ & $1863.426 \pm 29.422$ & 0.458 & $1873.380 \pm 21.677$ & $1891.026 \pm 27.341$ & $1840.609 \pm 35.385$ & 1.110 \\
\hline
\end{tabular}

Means bearing different superscripts $(a, b, c)$ within a column (between phase intervals) differ significantly $(\mathrm{p}<0.05)$, while means bearing common subscripts ( $\mathrm{x}$, $y, z)$ within a row (between the groups) do not differ significantly $(p>0.05)$. 
Miller et al., (1993) reported that feeding 0 and 1,000 IU vitamin E/head/day during dry period to cows led to significant $(\mathrm{p}<0.05)$ increase in the plasma total antioxidant activity at parturition. They also reported that the decrease of oxidative stress before parturition might be due to the increase of antioxidant protection that occurs in that particular physiological stage. This means that when the risk of oxidative damage increases, endogenous antioxidant protection increases too. On the other hand, Tanha et al., (2011) did not observe significant $(p>0.05)$ variation in total antioxidant status on day of calving and $7^{\text {th }}, 14^{\text {th }}, 21^{\text {st }}$ day before calving among glutamine supplemented Holstein cows. However, the TAS was found increased from prepartum to the day of calving.

Similar to present findings, Brezezinska et al., (1994) reported decrease in total antioxidant activity with approaching parturition in cows and on the day of parturition, FRAP values were non-significantly ( $p>0.05)$ higher in treatment group than that of control group. Further they reported, daily supplementation of vitamin E @ 1000 IU/cow/day resulted in 33, 43 and 61 per cent increase in plasma antioxidant capacity within 2, 4 and 6 weeks of supplementation during late gestation in cows.

According to Rajiv (2001), supplementation of $1500 \mathrm{IU} /$ day of vitamin E during 60 days pre-partum was sufficient to maintain optimum level of total antioxidant activity at parturition in buffaloes. Chatterjee et al., (2003) also found higher antioxidant status during parturition in the cows supplemented with vitamin E. They also found the values continued to decline till calving. Similarly, Chandra et al., (2013) reported significant $(\mathrm{p}<0.05)$ lower plasma TBARS values during prepartum compared with those during parturition and postpartum period in control and vitamin $\mathrm{E}$ treated groups, but postpartum plasma TBARS level was significant $(\mathrm{p}<0.05)$ lower in treatment group as compared to control group.

Panda et al., (2006) reported decrease in plasma antioxidant status at calving in Murrah buffaloes. Though the plasma total antioxidant activity (FRAP Values) continued to decline from $30^{\text {th }}$ days prepartum till calving. The status was non-significantly ( $p>0.05)$ higher on the day of parturition in vitamin E supplemented group as compared to control group of buffaloes. The FRAP values started increasing after parturition and reached normal range after 30 days of parturition. Wullepit et al., (2012) stated that plasma antioxidative status at the time of parturition showed a clear trend to be lower after calving in Holstein Friesian cows and Kankofera et al., (2010) also found highest total antioxidant capacity at 2 and 1 week ante-partum with a drop towards parturition suggesting the presence of oxidative stress during this time period. Total antioxidative capacity (TAC) increased in the prepartum period with a sharp decrease at parturition. During postpartum period, the values increased again with another decrease after 3 weeks postpartum in cows. Similarly, Hayajneh (2014) reported highest antioxidative capacity 3 to 5 weeks postpartum and the lowest at 3 to 0 weeks prepartum in dairy cattle. Moreover, retention of placenta was associated with oxidative stress as shown by the significantly lower value of total antioxidant capacity (TAC) as compared to non-retention group of buffaloes (Ahmed et al., 2009). Cigliano et al., (2014) found significantly $(\mathrm{p}<0.05)$ lower plasma concentration of TAC in early lactating than mid-late lactating buffaloes.

Even though the temporal pattern for the various antioxidants differed slightly, an overall trend could be noticed in that the highest values were observed at $60^{\text {th }}$ day prepartum with a drop towards parturition. This may be considered as the reaction of the macro 
organism to an increase in the contents of products of lipid and protein peroxidative damage appearing at similar time points. Total antioxidative capacity (TAC) increased in the prepartum period with a sharp decrease at parturition and the values again increased during postpartum. Similar time patterns were observed by Castillo et al., (2006) and concluded that the antioxidative system at that time period might be efficient for the protection against oxidative stress.

Measuring TAC is considered a valuable tool for determining the overall antioxidative potential of cells or the whole organism, provided repeated sampling during certain time periods. Nonetheless, due to the wide range of chemical properties of different antioxidants, it is not possible to cover all members of the antioxidative system against ROS with a single method. Several methods of TAC determination are in use, which differ in the range of antioxidants included.

Therefore, the measurement of single antioxidants might be useful for a more sophisticated interpretation of antioxidative/oxidative profiles.

\section{Acknowledgements}

Authors are grateful to Dean, College of Veterinary Science \& AH., Navsari Agricultural University, Navsari; Research Scientist, Livestock Research Station, NAU and all the staff of Department of Gynaecology \& Obstetrics for providing facilities and support to complete the present investigation.

\section{Conflict of interest statement}

Authors declare that they have no conflict of interest.

\section{References}

Ahmed, W.M., Abd El Hameed, Amal R., ElKhadrawy, H.H. and Hanafi, Emtenan M. (2009). Investigations on retained placenta in Egyptian buffaloes. Global Veterinaria, 3 (2): 120-124.

Benzie, F.F. and Strain, J.J. (1999). Ferric reducing/antioxidant power assay: Direct measure of total antioxidant activity of biological fluids and modified version of simultaneous measurement of total antioxidant power and ascorbic acid concentration. Methods in Enzymology, 299:15-23.

Brezezinska, S.E., Miller, J.K., Quigley, J.D., Moore, J.R. and Madsen, F.C. (1994). Antioxidant status of dairy cows supplemented prepartum with vitamin E and selenium. J. Dairy Sci., 77:30873095.

Castillo, C., Hernandez, J., Valverde, I., Pereira, V., Sotillo, J., Alonso, M.L. and Benedito, J.L. (2006). Plasma malonaldehyde (MDA) and total antioxidant status (TAS) during lactation in dairy cows. Res. Vet. Sci., 80(2), 133139.

Chandra, G., Aggarwal, A., Singh, A K., Kumar, M. and Upadhyay, R.C. (2013). Effect of vitamin $\mathrm{E}$ and zinc supplementation on energy metabolites, lipid peroxidation, and milk production in peripartum Sahiwal Cows. Asian-Aust. J. Anim. Sci., 26(11): 1569-1576.

Chatterjee, P.N., Kaur, Harjit and Panda, N. (2003). Effect of vitamin $\mathrm{E}$ supplementation on plasma antioxidant vitamins and immunity status of crossbred cows. Asian-Aust. J. Anim. Sci., 16(11): 1614-1618.

Cigliano, L., Strazzullo, M., Rossetti, C., Grazioli, G., Auriemma, G., Sarubbi, F., Iannuzzi, C., and Spagnuolo, M.S. (2014). Characterization of blood redox status of early and mid-late lactating dairy cows. Czech J. Anim. Sci., 59(4): 170-181.

Drackley, J.K. (1999). Biology of dairy cows during the transition period: the final frontier? J. Dairy Sci., 82: 2259-2273.

Fainaru, O., Almog, B. and Pinchuk, I. (2002). Active labour is associated with increased oxidisibility of serum lipids ex vivo. BJOG. 109(8): 938-41. 
Gitto, E., Reiter, R.J., Karbownik, M., Tan, D.X., Gitto, P., Barberi, S. and Barberi, I. (2002). Causes of oxidative stress in the pre- and perinatal period. Biol. Neonate, 81:146-157.

Harrison, J.H. and Conrad, H.R. (1984). Effect of selenium intake on selenium utilization by the non-lactating dairy cow. J. Dairy Sci., 67: 219-223.

Hayajneh, F.M.F. (2014). Facet of pregnancy stress on the antioxidative capacity in dairy cows. J. Exp. Bio. And Agril. Sci., 2(3):323-327.

Kankofera, Marta, Alberaa, Edyta., Feldmanb, Maren., Gundlingb, Natascha. And Hoedemakerb, Martina. (2010). Comparison of antioxidative/oxidative profiles in blood plasma of cows with and without retained fetal placental membranes. Theriogenology, 74: 13851395.

Miller, J.K., Brzezinska-Slebodzinska, E. and Madsen, F.C. (1993). Oxidative stress, antioxidants, and animal function. $J$. Dairy Sci., 76: 2812-2823.

Panda, N., Kaur, H. and Mohanty, T.K. (2006). Reproductive performance of dairy buffaloes supplemented with varying levels of vitamin E. Asian-Aust. J. Anim. Sci., 19(1): 19-25.

Paszkowski, T. and Clarke, R.N. (1996). Antioxidative capacity of preimplantation embryo culture medium declines following the incubation of poor quality embryos. Hum. Reprod., 11, 2493-2495.

Pressman, E.K., Cavanaugh, J.L. and Mingione, M. (2003). Effects of maternal antioxidant supplementation on maternal and fetal antioxidant levels: a randomized, double-blind study. Am. J.
Obstet. Gynecol., 189(6): 1720-5.

Rajiv. (2001). Influence of $\beta$-carotene and vitamin $E$ supplementation on udder health and immunocompetence in dairy cattle. Ph.D. Thesis, NDRI (Deemed University), Karnal, India.

Seagerson, E.C. and Libby, D.W. (1982). Ova fertilization and sperm number per fertilized ovum for selenium and vitamin E treated Charolais cattle. Theriogenology, 17: 333-341.

Sugino, N., Takiguchi, S. and Kashida, S. (2000). Superoxide dismutase expression in the human corpus luteum during the menstrual cycle and in early pregnancy. Mol. Hum. Reprod., 6(1): 19-25.

Tanha, T., Amanlou, H., Chamani, M., Ebrahimnezhad, Y., Salamatdost, R., Maheri, N. and Fathi, M. (2011). Glutamine and Glutathione peroxidase activity (GPX) and Total Antioxidant Capacity (TAS) in Prepartum in Holstein Dry Cows. Annals of Biol. Res., 2(5):113119.

Weiss, W.P. and Spears, J.W. (2006). Vitamin and trace mineral effects on immune function of ruminants. In: Sejrsen, K., Hvelplund, T., Nielsen, M.O. (Eds.), Ruminant Physiology. Wageningen Academic Publishers, Utrecht, The Netherlands, pp. 473-496.

Wullepit, N., Hostens, M., Ginneberge, C., Fievez, V., Opsomer, G., DeSmet, S. and Fremaut, D. (2012). Influence of a marine algae supplementation on the oxidative status of plasma in dairy cows during the periparturient period. Preventive Vet. Med., 103: 298-303.

\section{How to cite this article:}

Modi, L.C., C.T. Khasatiya, Sandhya Chaudhary, N.F. Chaudhari, C.F. Chaudhari and Falguni Modi. 2018. Influence of Antioxidant Administration during Periparturient Period on Total Antioxidant Status in Surti Buffaloes. Int.J.Curr.Microbiol.App.Sci. 7(10): 1954-1960. doi: https://doi.org/10.20546/ijcmas.2018.710.225 